Research article

\title{
Occurrence of Genus Microcystis Lemmerm. from water bodies of Maldah district, West Bengal, India
}

\begin{abstract}
Pratibha Gupta
Botanical Survey of India, Ministry of Environment, Forest and Climate Change, Government of India Acharya Jagadish Chandra Bose Indian Botanic Garden, Howrah-711103, West Bengal, India

*Corresponding Author: drpratibha2011@ rediffmail.com

[Accepted: 28 July 2019]

Abstract: Present investigation deals with systematic enumeration of Genus Microcystis. collected from different water bodies of Maldah District, West Bengal and its impacts for which systematic survey and collection of the samples was carried out from different water bodies of all administrative blocks of Maldah District namely Ratua I, Ratua II, Harishchandrapur I, Harishchandrapur II, Chanchal I, Chanchal II, Manikchak, Gazol, Habibpur, Bamangola, Old Maldah, English Bazar and Kaliachak. Altogether ten species of Genus Microcystis viz. Microcystis aeruginosa, M. flos-aquae, M. ichthyoblabe, M. novacekii, $M$. panniformis, M. protocystis, M. pseudofilamentosa, M. robusta, M. viridis and M. wesenbergii were recorded from different water bodies of Maldah District, West Bengal. Out of ten, four species of Genus Microcystis viz. Microcystis ichthyoblabe, M. panniformis, M. wesenbergii and M. novacekii have been reported for the first time from water bodies of block Ratua I, Old Maldah and English Bazar of Maldah District, West Bengal. Some of the species of Microcystis are bloom forming. Taxonomically, the Genus Microcystis is very important because of its characteristic features among the cyanophycean forms, global distribution and occurrence.
\end{abstract}

Keywords: Survey - Collection - Identification - Microcystis - Systematic enumeration.

[Cite as: Gupta P (2019) Occurrence of genus Microcystis Lemmerm. from water bodies of Maldah district, West Bengal, India. Tropical Plant Research 6(2): 233-240]

\section{INTRODUCTION}

Maldah district is flood prone area. That is why one of the important district among 19 districts of West Bengal. In terms of duration and frequency of flood and its recurrences is concerned, Maldah district is defined as a chronically flood-affected area. Here the practice of aqua culture, cultivation of rice and Makhana (Eurayle ferox Salisb.) are other aspects on which socio-economic condition and livelihood of the district depends. To meet the requirements, huge number of big and small size 'bils' (swamps), 'dighi' and 'ponds' depending upon land area available to individuals are made by them. Such water bodies often get eutrophicated by micro and macrophytes as a result of contaminants from various non-point and point sources like runoff of agriculture fields in which huge quantity of fertilizers and pesticides is used and civic as well as industrial pollutants respectively. Among the aquatic flora, diversity and distribution of microscopic flora is much greater having both beneficial and harmful properties. Microcystis Lemmerm. is the main genus found worldwide (Gupta 2012). Some of the species of Genus Microcystis Lemmerm. are bloom forming species (Gupta \& Kumar 2005) of cyanoprokaryota also known as cyanobacteria/cyanophyceae/blue-green algae which floats on the surface of the water and form scum due to buoyancy produce by intracellular gas vacuolation (Walsby 1972, Paerl \& Ustach 1982, Kumar \& Gopal 1999, 2003). Due to scum formation, bluish-greenish colour of the water changed on ageing and break down of cells resulting turning it as yellowish-greenish. Present study deals with systematic enumeration of Genus Microcystis Lemmerm. collected from different water bodies of Maldah District, West Bengal and its impacts on aquatic environment which is unexplored area.

\section{MATERIALS AND METHODS}

Maldah district is situated in West Bengal of north-east India and lies between $24^{\circ} 41^{\prime} 20^{\prime \prime}$ and $25^{\circ} 32^{\prime} 08^{\prime \prime}$ 
North Latitude and $87^{\circ} 45^{\prime} 50^{\prime \prime}$ and $88^{\circ} 28^{\prime} 10^{\prime \prime}$ East Longitude, extends over $3733.17 \mathrm{~km}^{2}$ with total population 32,90,468 as per Census, 2001 (BAES 2004) and English Bazar is the District Administrative Headquarter. The district is bounded to its south by the district of Murshidabad across the river Ganga, by Rajshahi district of Bangladesh and Dakshin Dinajpur district to its east and north-east, by Uttar Dinajpur district to its direct north and by the Purnea of Bihar to its direct west and by Sahibganj of State of Jharkhand across the Ganga to the south-west (Fig. 1).

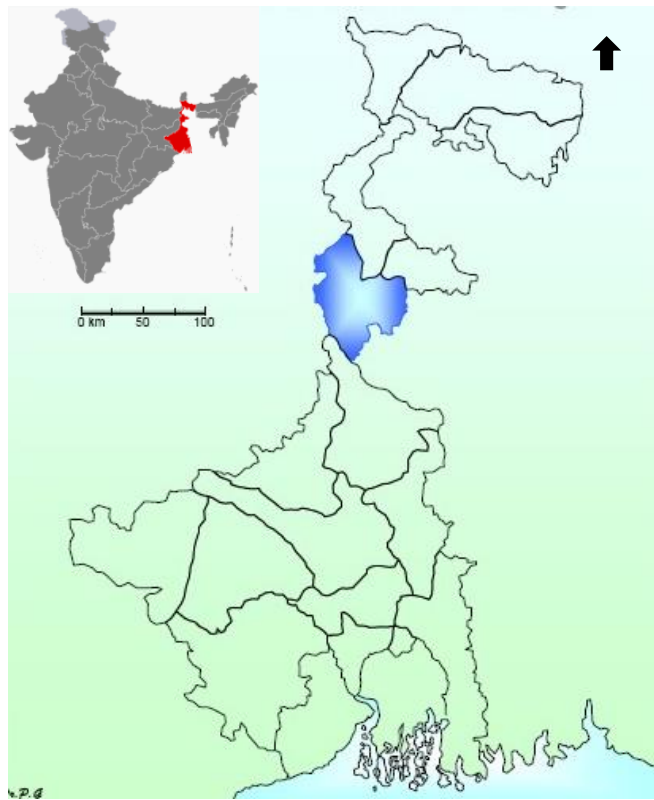

Figure 1. Location of the study site: Maldah district, West Bengal, India.

During the survey all administrative blocks of Maldah district namely Ratua I, Ratua II, Harishchandrapur I, Harishchandrapur II, Chanchal I, Chanchal II, Manikchak, Gazol, Habibpur, Bamangola, Old Maldah, English Bazar and Kaliachak were visited and samples sampled from different water bodies of Maldah District, W.B. Samples were sampled randomly towing Phytoplankton net to a distance of 1.0$5.0 \mathrm{~m}$ depending up on depth of water bodies. The samples were preserved in $15.0 \mathrm{ml}$ screw cap Borosil glass specimen vials to avoid any chemical reaction. To take samples from other water bodies, Phytoplankton net was thoroughly washed with clean water after collection of each sample. Samples were preserved by adding 2-3 drops of 4\% Formalin solution. Specimens were observed under Leica DM 2500 Microscope and photomicrograph of each specimen was taken by DFC 500 digital camera with annotation using Leica QWin V 3.2 Image Processing and Analysis Software and Leica Application Suit V4. Specimens were identified by consulting standard books, monograph (Geitler 1932, Tiffany \& Britton 1952, Desikachary 1959, Prescott 1982, Anand 1989, 1998, Komárek \& Anagnostidis 1998). The authority name of each species is cited in the text as described in 'Authors of Plant Names' (Brummitt \& Powell 1992), title of the books in citation is cited in accordance with Stafleu \& Cowan (1976, 1979, 1981, 1983, 1985, 1986, 1988) and supplements as described by Stafleu \& Mennege (1992, 1993, 1995, 1997, 1998, 2000), whereas Journals, Periodicals with Botanical content as described in "Botanico-Periodicum-Huntianum", BPH-2 (Bridson 2004a, b).

\section{RESULTS}

Systematic Enumeration

Systematic studies carried out on Genus Microcystis Lemmerm. from different water bodies of Maldah district, West Bengal. Taxonomic enumeration of altogether ten identified species of Genus Microcystis Lemmerm. of Maldah District of West Bengal are described here along with their details.

Microcystis Lemmerm. Kryptogamenfl. Mark Brandenb. 3(1): 45, 1907

Colonies spherical, oval, lobate to irregular or elongate in several species irregularly clathrate, sometimes composed of subcolonies or clustered together, with irregularly, sparsely or densely arranged cells in common fine mucilage, colourless, usually homogeneous or indistinctly lamellate, diffluent or distinct and delimited, in many species with refractive outline (surface); around individual cells gelatinous envelope absent; cells spherical or hemispherical, many in spherical, ellipsoidal or irregularly overlapping or net like colony, gas vesicles often present. Ten species have been reported from this region. 
Key to the Species

1a. Colonies clathrate .2

1b. Colonies not clathrate

2a. Colony enveloped by diffluent somewhat indistinct slime

M. aeruginosa

2b. Colony rounded, sheath distinct. M. robusta

3a. Mucilage of the colony not clearly restricted. M. potocystis 3b. Mucilage with definite margins. M. viridis

3c. Mucilage with indistinct margins. 4

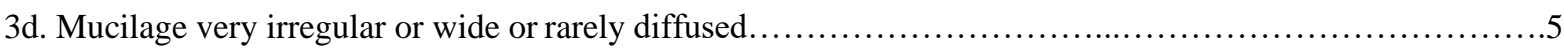

4a. Colonies almost spherical, ellipsoidal or somewhat elongate............................... flos-aquae

4b. Colonies long, narrow, with series of partial colonies.............................. pseudofilamentosa

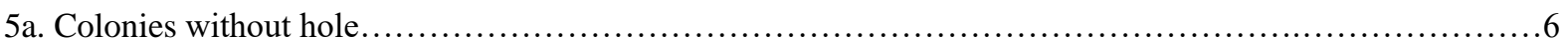

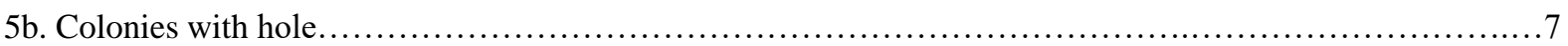

6a. Cells densely agglomerated in centre.................................................novacekii

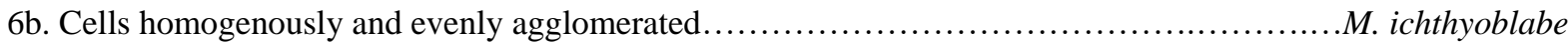

7a. Colony lobate composed with connected spheroidal subcolonies.............................. wesenbergii

7b. Colony not lobate composed with connected spheroidal sub-colonies and flattend............... panniformis

Microcystis aeruginosa (Kütz.) Kütz., Tab. Phycol. 1: 6, 8, t.8, f. 1. 1846; Desikachary, Cyanophyta 93, t.17, f. 1-2, 6 \& t.18, f. 10. 1959.

(Fig. 2A) Micraloa aeruginosa Kütz., Linnaea 8: 371, t.8, f. 23. 1833.

An ovate, spherical, or irregularly lobed, clathrate and mucilaginous colony of numerous spherical cells much crowded within a gelatinous matrix; mucilage colourless, structureless, diffluent, sometimes forming distinct cell contents blue-green, highly granular with conspicuous pseudo vacuoles.

Dimension: Cells 3.0-7.0 $\mu \mathrm{m}$ in diameter.

Distribution: Bil (Ghogha and Manna), Dighi (Sukan) and Pond (Bhadobartola, Meenatula, Rohini, Shivrampalli, Salami Darwaja, Samda, Kuppa, Jorkuppa and Damua).

Microcystis flos-aquae (Wittr.) Kirchn., in Engl. \& Prantl, Nat. Pflanzenfam., I. (1a): 56, f. 49 N. 1898;

Desikachary, Cyanophyta 94, t.17, f. 11 \& t.18, f. 11.1959.

(Fig. 2B)

Microcystis aeruginosa f. flos-aquae (Wittr.) Elenkin, Monogr. Alg. cyanophyc., Pars Gen. 1: 103, 1938.

Colony ellipsoidal or more or less elongate or roughly spherical, not clathrate; colonial mucilage indistinct; cells spherical with gas-vacloles.

Dimension: Cells 3.0-7.0 $\mu \mathrm{m}$ in diameter.

Distribution: Dighi (Kalua and Sukan).

Microcystis ichthyoblabe (G.Kunze) Kütz., Phycol. general. 170, 1843; Komárek \& Anagn., Cyanoprokaryota

Part 1: Chroococcales 19(1): 226, f. 297. 1998.

(Fig. 2C)

Granularia ichthyoblabe G.Kunze in E.Schmalz, Flora 6: 566, 1823.

Colony large, irregular, compact, without holes, mostly flattened, often form cell clusters or sub colonies in common mucilage, later on disintegrated in to small groups of aggregated cells; margins of colonies irregular, indistinct, diffuse, irregularly overlapping cells; cells spherical, densely homogeneously and evenly accumulated.

Dimension: Cells 2.0-3.7 $\mu \mathrm{m}$ in diameter.

Distribution: Pond (Bhadobartola).

Microcystis novacekii (Komárek) Compère, Bull. Jard. Bot. Natl. Belg. 44: 19, 1974; Komárek \& Anagn., Cyanoprokaryota Part 1: Chroococcales 19(1): 220, f. 302. 1998.

(Fig. 2D)

Diplocystis novacekii Komárek, in Komárek \& Ettl., Alg. Stud.: 63, t.6, f. 1-4. 1958.

Colony almost spheroidal and slightly flattened, sometimes cells aggregated together; cells densely agglomerated in the centre of the colony, few solitary cells in enveloping mucilage.

Dimension: Cells 2.3-6.0 $\mu \mathrm{m}$ in diameter.

Distribution: Dighi (Bara Sagar). 

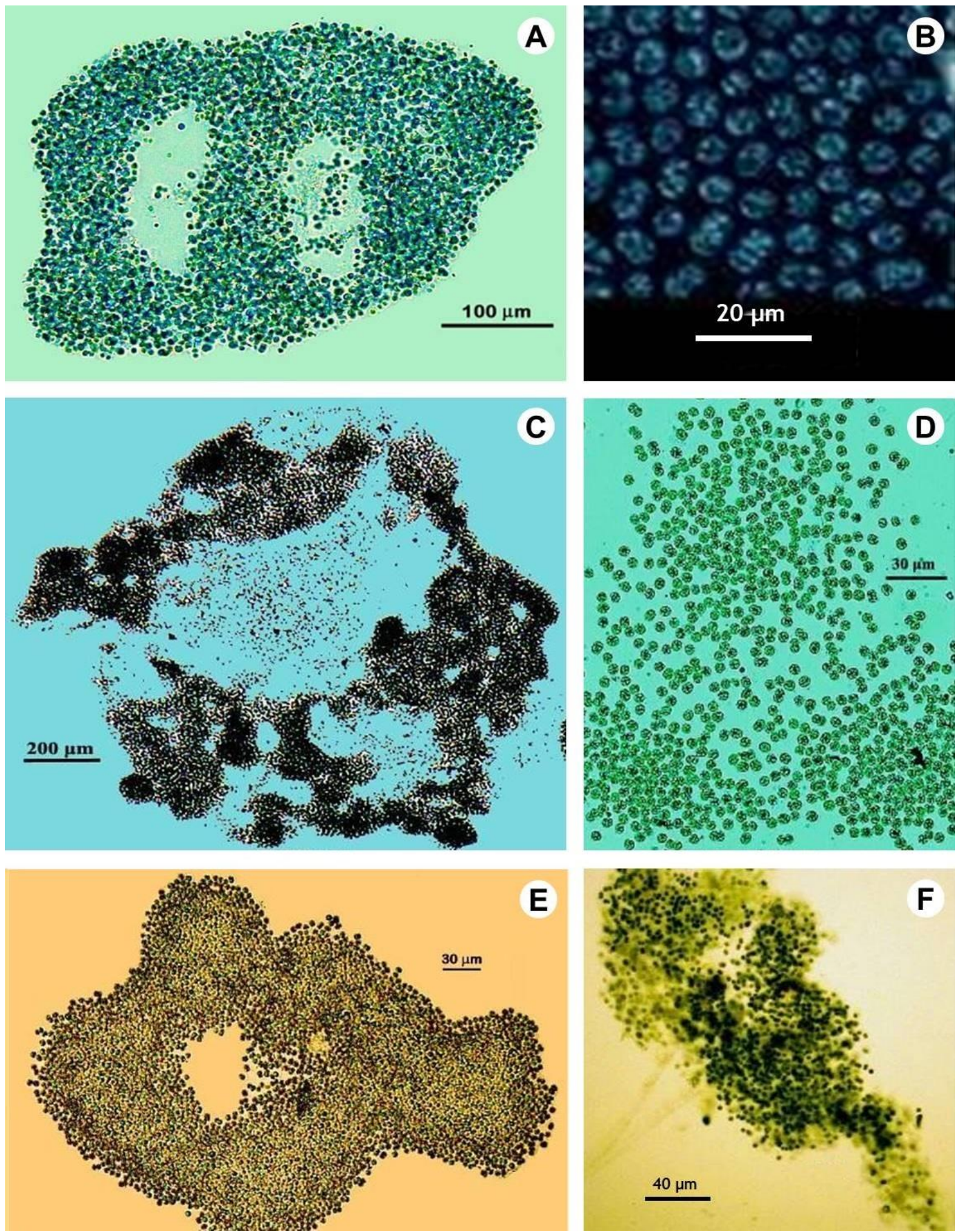

Figure 2. A, Microcystis aeruginosa (Kütz.) Kütz.; B, M. flos-aquae (Wittr.) Kirchn.; C, M. ichthyoblabe Kütz.; D, Microcystis novacekii (Komárek) Compère; E, M. panniformis Komárek; F, M. protocystis Crow.

Microcystis panniformis Komárek, Komárk.-Legn., C.L. Sant’Anna, M.T.P. Azevedo \& Senna, Crypto. Algol.

23: 165, f. 14-28. 2002; Komárek \& Anagn., Cyanoprokaryota Part 1: Chroococcales 19(1): 226, f. 297. 1998.

(Fig. 2E)

Colony flat, irregular with small holes; margins of the colonies smooth or irregular; cells regularly densely and smoothly accumulated.

Dimension: Cells 2.5-4.9 $\mu \mathrm{m}$ in diameter.

Distribution: Pond (Bhadobartola). 

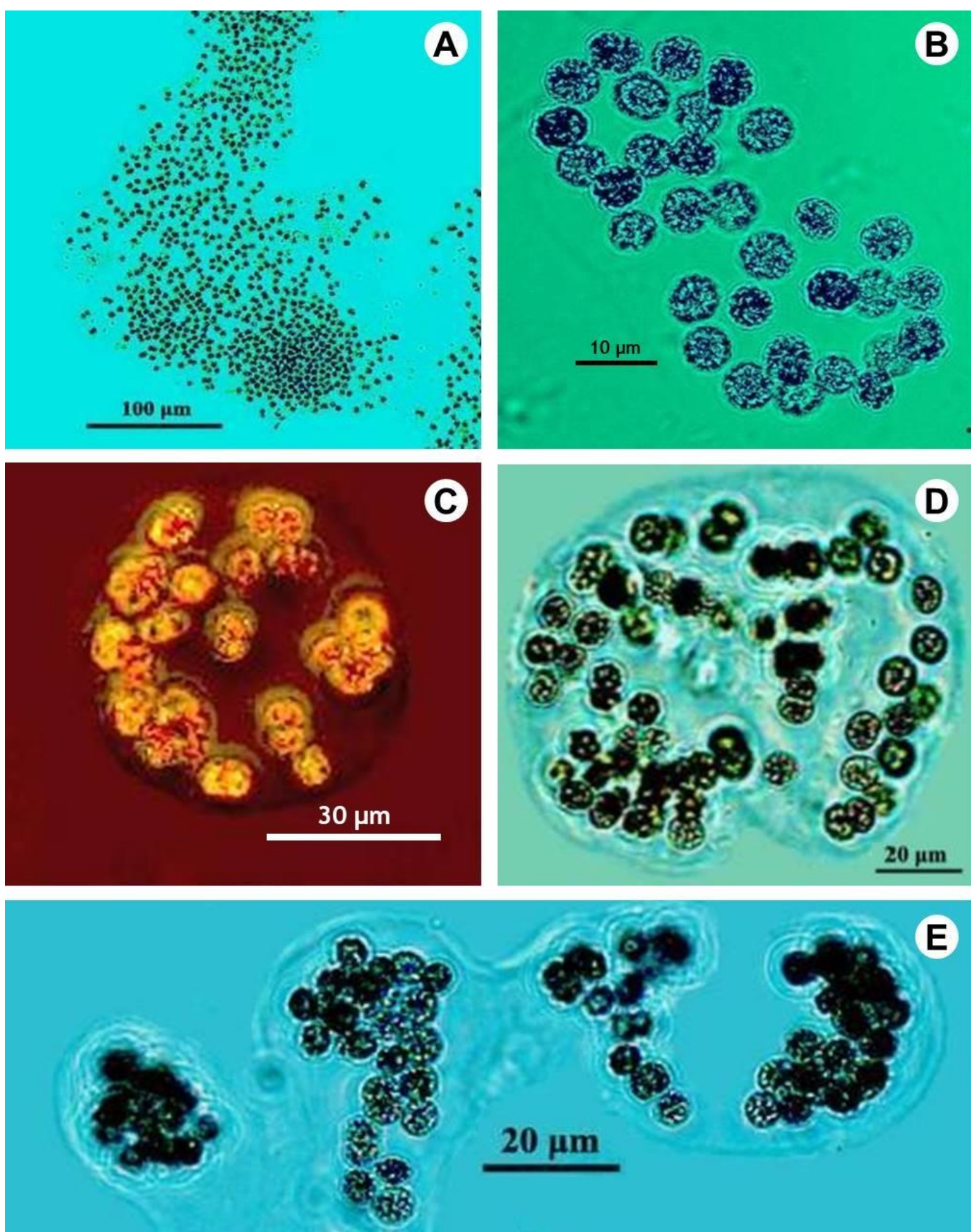

Figure 3. A, Microcystis pseudofilamentosa Crow; B, M. robusta (H.W.Clark) Nygaard; C, M. viridis (A.Braun) Lemmerm.; D-E, M. wesenbergii (Komárek) Komárek.

Microcystis protocystis Crow, New Phytol. 22: 62, t.1, f. d. 1923; Desikachary, Cyanophyta 91, t.20, f. 4. 1959.

(Fig. 2F)

Colony irregular, mostly diffuse with the limits of colonial mucilage, not clearly restricted; cells spherical, many varying in the mode of aggregation from closely packed to generally dissociated.

Dimension: Cells 3.3-6.0 $\mu \mathrm{m}$ in diameter.

Distribution: Dighi (Bara Sagar).

Microcystis pseudofilamentosa Crow, New Phytol. 22: 64, t.1, f. e-f. 1923; Desikachary, Cyanophyta 95, t.18,

f. $9 \&$ t.20, f. 1.1959.

(Fig. 3A) 
Colony varying in size, usually 220 - $290 \mu \mathrm{m}$ long; margins of the colonial mucilage indistinct; mostly partial colonies; cells spherical with gas-vacuoles.

Dimension: Cells 3.2-6.5 $\mu \mathrm{m}$ in diameter.

Distribution: Dighi (Bara Sagar).

Microcystis robusta (H.W.Clark) Nygaard, Dansk Bot. Ark. 4(10): 8, f. 1-4. 1925; Desikachary, Cyanophyta 85, t.17, f. 7-10. 1959. Clathrocystis robusta H.W.Clark, Proc. Biol. Soc. Washington 2: 94, 1909. (Fig. 3B)

Colony rounded first, later on irregularly elongated and clathrate; sheath distinct; cells spherical.

Dimension: Cells 5.6-7.0 $\mu \mathrm{m}$ in diameter.

Distribution: Dighi (Bara Sagar and Sukan).

Microcystis viridis (A.Braun) Lemmerm., Abh. Naturwiss. Vereins Bremen 17: 342, 1903; Desikachary, Cyanophyta 87, t.18, f. 1-6. 1959.

(Fig. 3C)

Polycystis viridis A.Braun, Fl. eur. alg. 2: 53, 1865.

Colony rounded, sometimes numbers of daughter colonies surrounded by common mucilaginous sheath, margins of colonial mucilage definite; cells spherical, even single cell frequently develop a thick mucilage envelop all round and split from the thallus by further division, these cells later give rise to new colonies.

Dimension: Cells 3.5-7.0 $\mu \mathrm{m}$ in diameter.

Distribution: Pond (Shivrampalli).

Microcystis wesenbergii (Komárek) Komárek ex Komárek, in Kondrateva Cvetenie vody, Naukova Dumka Kiev 32, 1968; Komárek \& Anagn., Cyanoprokaryota Part 1: Chroococcales 19(1): 232, f. 305.1998.

Diplocystis wesenbergii Komárek, Komárek \& Ettl., Alg. Stud.: 68, t.7, f. 1-4. 1958.

(Fig. 3D, E)

Colony irregular, spheroidal to lobate or elongate with holes when old; mostly composed with connected spheroidal subcolonies; cells sparsely to densely accumulated often near the surface of subcolonies.

Dimension: Cells 4.0-8.6 $\mu \mathrm{m}$ in diameter.

Distribution: Dighi (Sukan).

\section{DISCUSSION AND CONCLUSION}

Altogether 10 species have been reported from 14 water bodies of Maldah District, West Bengal. Out of 15 blocks of Maldah District, species of Microcystis Lemmerm. Were recorded from 09 Ponds, 02 Bils, and 03 Dighi of 06 blocks namely Ratua I, Harishchandrapur I, Harishchandrapur II, Chanchal II, Old Maldah and English Bazar. It was observed that some of the species have been recorded in more than one water bodies like Microcystis flos-aquae (Wittr.) Kirchn. from Kalua and Sukan Dighi of Old Maldah block, M. robusta (H.W.Clark) Nygaard from Bara Sagar and Sukan Dighi of English Bazar and Old Maldah block respectively. M. aeruginosa (Kütz.) Kütz. was observed from maximum 12 water bodies of 06 blocks viz. Chanchal - II (Ghogha bil), Old Maldah (Sukan Dighi, Meenatula, Rohini, Shivrampalli, Salami Darwaja ponds) English Bazar (Samda, Kuppa and Jorkuppa) Ratua I block (Bhadobartola Pond), Harishchandrapur I (Damua Pond) and Harishchandrapur - II (Manna bil) and showed massive presence of Microcystis colonies while in Meenatula and Bhadobartola ponds it was recorded almost axenic. However, single species of Microcystis Lemmerm. i.e. M. ichthyoblabe (G.Kunze) Kütz. and M. panniformis Komárek, Komárk.Legn., C.L. Sant'Anna, M.T.P. Azevedo \& Senna observed from Bhadobartola Pond of block Ratua I; $M$. novacekii (Komárek) Compère, M. protocystis Crow, M. pseudofilamentosa Crow from Bara Sagar Dighi of English Bazar; M. viridis (A.Braun) Lemmerm. and M. wesenbergii (Komárek) Komárek ex Komárek from Shivrampalli Pond and Sukan Dighi of Old Maldah block respectively. It was observed that maximum species of Microcystis Lemmerm. have been recorded from Sukan Dighi of Old Maldah and Bara Sagar Dighi of English Bazar block of Maldah District of West Bengal. Four species of Microcystis Lemmerm. viz. M. ichthyoblabe (G.Kunze) Kütz., M. novacekii (Komárek) Compère, M. panniformis Komárek and $M$. wesenbergii (Komárek) Komárek ex Komárek new records from West Bengal (Gupta 2017). Toxic and bloom forming species viz. M. aeruginosa (Kütz.) Kütz., M. flos-aquae (Wittr.) Kirchn., M. novacekii (Komárek) Compère, M. panniformis Komárek, M. viridis (A.Braun) Lemmerm. and M. wesenbergii (Komárek) Komárek ex Komárek found in Maldah District, W. B. Microcystis protocystis Crow produced the highest level of lipids so it is the most promising species for utilization at an industrial scale and may be used for the production of Biofuel (Cordeiro 2017). Toxicity of the specific taxa becomes both taxonomically and ecologically very important. M. aeruginosa produced neurotoxins and hepatotoxins and other species of www.tropicalplantresearch.com 
Microcystis Lemmerm. viz. M. flos-aquae (Wittr.) Kirchn., M. ichthyoblabe (G.Kunze) Kütz., M. novacekii (Komárek) Compère, M. viridis (A.Braun) Lemmerm., M. wesenbergii (Komárek) Komárek ex Komárek also produced toxins (Komárek \& Anagnostidis 1998, Fastner et al. 2001, Komárek \& Komárkova 2002, Kurmayer et al. 2002, Via-Ordorika et al. 2004, Gupta \& Husain 2007, Šejnohová 2008). Further detail analysis of toxins producing species found abundantly in water bodies is required because in water bodies of Maldah District practice of aqua culture is common and used for cultivation of rice and Makhana (Eurayle ferox Salisb.) on which socio-economic condition and livelihood of the district depends. Beside this, Microcystis aeruginosa (Kütz.) Kütz. also having antiviral activity against influenza A virus (Nowotny et al. 1997). These studies may be utilized by experimental, evolutionary and ecological researchers worldwide and fill the gap in our existing knowledge.

\section{ACKNOWLEDGEMENTS}

The author is thankful to the Director, Botanical Survey of India, Ministry of Environment Forest \& Climate Change, Government of India, Kolkata for proving the necessary laboratory facilities for completion of this work.

\section{REFERENCES}

Anand N (1989) Hand book of blue green algae. Bishen Singh Mahendra Pal Singh, Dehra Dun, 79 p.

Anand N (1998) Indian Freshwater Microalgae. Bishen Singh Mahendra Pal Singh, Dehra Dun, 94 p.

BAES (2004) District Statistical Handbook, Maldah. Bureau of Applied Economics and Statistic, Government of West Bengal, Kolkata, 174 p.

Bridson GDR (2004a) Botanico-Periodicum Huntianum (BPH - 2). $2^{\text {nd }}$ Ed., 1(A - M): 1-819 p.

Bridson GDR (2004b) Botanico-Periodicum Huntianum (BPH - 2). $2^{\text {nd }}$ Ed., 2(N - Z): 821-1470 p.

Brummitt RK \& Powell CE (1992) Authors of Plant Names. Royal Botanic Gardens, Kew, 732 p.

Cordeiro Raquel S, Vaz Izabela CD, Magalhães Sérgia MS \& Barbosa Francisco AR (2017) Effects of nutritional conditions on lipid production by cyanobacteria. Anais da Academia Brasileira de Ciências 89(3 Suppl.): 2021-2031.

Desikachary TV (1959) Cyanophyta. Indian Council of Agricultural Research, New Delhi, 686 p.

Fastner J, Erhard M \& Dohren H (2001) Determination of oligopeptide diversity within a natural population of Microcystis spp. (Cyanobacteria) by typing single colonies by matrix- assisted laser desorption ionizationtime of flight mass spectrometry. Applied \& Environmental Microbiology 67: 5069-5076.

Geitler L (1932) Cyanophyceae. In: Rabenhorst L (ed.) Kryptogammenflora von Deutschland, Osterreich, under de Sweitz. Akad. Verlagsges, Leipzing 14: 1196 p.

Gupta P \& Husain MM (2007) Cyanobacterial Toxins - Monitoring and Management. Pollution Managements. 1(17): 249-290.

Gupta P \& Kumar S (2005) Microcystis aeruginosa Kütz. bloom in ponds of Maldah District, West Bengal. Bulletin of the Botanical Survey of India 47(1-4): 115-120.

Gupta P (2012) Algae of India - A checklist of Cyanoprokaryota (Cyanophyceae). Botanical Survey of India, Ministry of Environment, Forest and Climate Change, Government of India, Kolkata, 160 p.

Gupta P (2017) New record of Cyanoprokaryotes from West Bengal in Maldah District. Tropical Plant Research 4(3): 421-432.

Komárek J \& Anagnostidis K (1998). Cyanoprokaryota 1. Teil: Chroococcales. In: Ettl H, Gärtner G, Heynig H \& Mollenhauer D. (eds) Süsswasserflora von Mitteleuropa, Gustav Fischer, Jena-Stuttgart-Lübeck-Ulm. 19(1): 548.

Komárek J \& Komárkova J (2002) Review of European Microcystis- morphospecies (Cyanoprokaryotes) from nature. Czech Phycology 2: 1-24.

Kumar S \& Gopal K (1999) Freshwater cyanobacterial toxins and its effects. Proceedings of $1^{\text {st }}$ National Conference on Aquatic Biotoxins. held in ITRC, Lucknow between 25-26 Nov. 2019, pp. 5-6.

Kumar S \& Gopal K (2003) Cyanobacterial toxins: Occurrence, properties and biological significance. In: Singh J \& Pandey G (eds) Natural Resource Management and Conservation. Kalyani Publishers, New Delhi, pp 52-74.

Kurmayer R, Dittmann E, Fastner J \& Chorus I (2002) Diversity of microcystin genes within a population of the toxic cyanobacterium Microcystis spp in Lake Wannsee (Berlin, Germany). Microbial Ecology 43: 107-118.

Nowotny A, Mentel R, Wegner U, Mundt Sabine \& Lindequist Ulrike (1997) Antiviral Activity of an Aqueous Extract of the Cyanobacterium Microcystis aeruginosa. Phytotherapy Research 11: 93-96.

www.tropicalplantresearch.com 
Paerl HW \& Ustach JF (1982) Blue-green algal scum: An explanation for their occurrence during freshwater blooms. Limnology and Oceanography 21: 212-217.

Prescott GW (1982) Algae of the Western Great Lakes Area. Otto Koeltz Science Publishers, W. Germany 977 pp.

Šejnohová L (2008) Microcystis New findings in peptide production, taxonomy and autecology by cyanobacterium Microcystis, (Ph.D. Thesis). Czech Academy of Sciences, Průhonice.

Stafleu FA \& Cowan RS (1976) Taxonomic literature. Bohn, Scheltema \& Holkema, Utrecht 1(A-G): 1134 pp.

Stafleu FA \& Cowan RS (1979) Taxonomic literature. Bohn, Scheltema \& Holkema, Utrecht, dr. W. Junk b. v., Publishers, The Hague 2(H-Le): 990 pp.

Stafleu FA \& Cowan RS (1981) Taxonomic literature. Bohn, Scheltema \& Holkema, Utrecht, dr. W. Junk b. v., Publishers, The Hague 3(Lh-O): 980 pp.

Stafleu FA \& Cowan RS (1983) Taxonomic literature. Bohn, Scheltema \& Holkema, Utrecht/Antwerpen, dr. W. Junk b. v., Publishers, The Hague/Boston 4(P - Sak): 1188 pp.

Stafleu FA \& Cowan RS (1985) Taxonomic literature. Bohn, Scheltema \& Holkema, Utrecht, dr. W. Junk b. v., Publishers, The Hague 5(Sal-Ste): 1066pp.

Stafleu FA \& Cowan RS (1986) Taxonomic literature. Bohn, Scheltema \&Holkema, Utrecht, dr. W. Junk b. v., Publishers, The Hague/Boston 6(Sti-Vuy):926 pp.

Stafleu FA \& Cowan RS (1988) Taxonomic literature. Bohn, Scheltema \& Holkema, Utrecht/Antwerpen, dr. W. Junk b. v., Publishers, The Hague/Boston 7(W-Z): 653 pp.

Stafleu FA \& Mennege EA (1992) Taxonomic literature, Koeltz Scientific Books Königstein, Germany, Suppl. 1(A-Ba): 442 pp.

Stafleu FA \& Mennege EA (1993) Taxonomic literature, Koeltz Scientific Books Königstein, Germany, Suppl. 2(Be-Bo): 464 pp.

Stafleu FA \& Mennege EA (1995) Taxonomic literature, Königstein, Germany, Suppl. 3(Br-Ca): 550 pp.

Stafleu FA \& Mennege EA (1997) Taxonomic literature, Koeltz Scientific Books, Königstein, Germany, Suppl. $4(\mathrm{Ce}-\mathrm{Cz}): 614 \mathrm{pp}$

Stafleu FA \& Mennege EA (1998) Taxonomic literature, Koeltz Scientific Books, Königstein, Germany, Suppl. 5(Da-Di): $432 \mathrm{pp}$.

Stafleu FA \& Mennege EA (2000). Taxonomic literature, Koeltz Scientific Books, Königstein, Germany, Suppl. 6(Do-E): 518 pp.

Tiffany LH \& Britton ME (1952) The Algae of Illinois. The University of Chicago Press, Chicago, Cambridge University Press, London, 397 pp.

Via-Ordorika L, Fastner J, Kurmayer R, Hisbergues M, Dittmann E, Komárek J, Erhard M \& Chorus I (2004) Distribution of microcystin-producing and non-microcystin-producing Microcystis sp in European freshwater bodies: detection of microcystins and microcystin genes in individual colonies. Systematic and Applied Microbiology 27: 592-602.

Walsby AE (1972) Structure and function of gas vacuoles. Bacteriological Reviews 36: 1-32. 